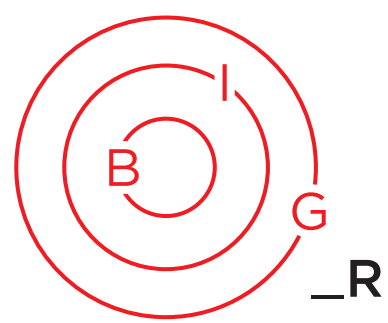

ESSAY

SPECIAL ISSUE

\title{
Ukrainian Cross-Border Governance since the Beginning of COVID-19
}

\author{
Natalia Horobets i \\ Tatiana Shaban ii
}

\begin{abstract}
European countries that are normally associated with freedom of movement have temporarily closed their internal (within the European Union) and external borders in response to the outbreak of COVID-19 starting spring 2020. Border closures have heavily impacted the whole European region, including its Eastern European neighbours. As of March, Ukraine stopped all regular passenger services, so that people were not able to leave the country by plane, train or bus. It seriously complicated routine activities of those Ukrainians who were planning to travel out of their country through Europe (and Russia) for various purposes, including work, study, and family visits.
\end{abstract}

\section{Introduction}

Ukraine followed the European integration course since it gained independence in 1991 by liberalising its market, introducing governmental reforms and committing to the rule of law. European Union (EU) Member States supported democratic changes and good governance reforms in Ukraine, provided financial aid and professional expertise, and introduced other supportive

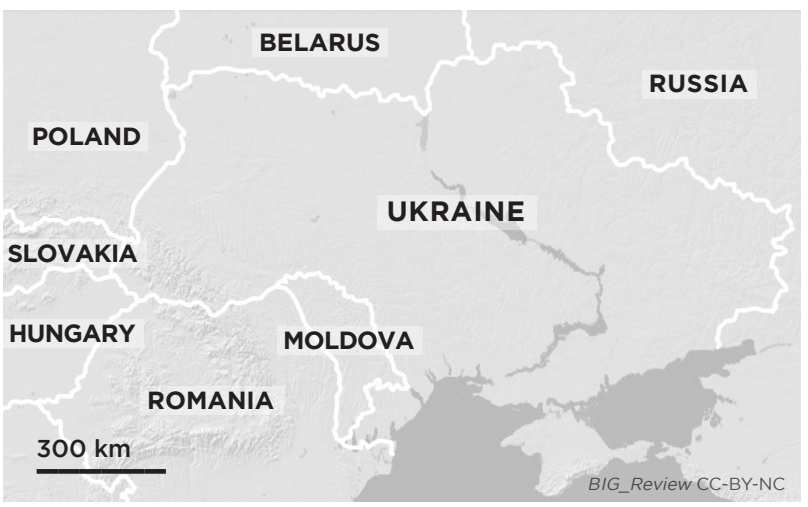

actions to the government and people of Ukraine. The EU visa-free regime with Ukraine, announced in June 2017, was among those numerous arrangements aimed at facilitating people-to-people contacts as an important condition for further development of economic, humanitarian, cultural, scientific, and other ties between the EU and Ukraine. According to Hugues Mingarelli, who served as the Head of the EU Delegation to Ukraine in 2017, Ukrainians had the opportunity to travel to 33 countries of Western Europe without any visa requirements, which made a dream of being in "one (European) family soon" more real than ever (Mingarelli 2017).

\section{Ukrainian Cross-Border Governance}

Negotiations of the Visa Facilitation Regime between the EU and Ukraine started long before 2017 and was accompanied by a Political Declaration on Local Border Traffic (LBT) ${ }^{1}$ from Poland, Hungary, the Slovak

i Natalia Horobets, professor, Department of Law, Sumy Branch of Kharkiv National University of Internal Affairs. Contact: justitsia.n@gmail.com

ii Tatiana Shaban, Post-Doc Scholar, Centre for Global Studies, University of Victoria, Canada. Contact: tshaban@uvic.ca https://www.linkedin.com/in/tatiana-shaban-81759925/ https://twitter.com/tatiana903?lang=en 
Republic, and Romania. The 2006 EU Regulation made it possible for EU countries and Schengen non-EU members (Schengen refers to an agreement between European countries to lift border controls between themselves) to conclude agreements with neighbouring states on a visa-free land-border regime for residents within a 30-to-50 kilometre zone on either sides of the border (Yeliseyeu 2014, 11). After the 2014 political revolution in Ukraine, followed by economic collapse and civil war in the eastern part of the country, millions of Ukrainians traveled to Poland and further west to find work or refuge. According to Ukraine's Chief of the Ukrainian Mission of the International Organisation of Migration (IOM) Manfred Profazi, "migrant workers are clearly biggest investors in the economy of Ukraine" (IOM 2016). The largest influx of Ukrainians to work in Poland for industries like catering, construction, manufacturing, farming, etc, was recorded in 2017, as shown in the number of work permits issued by year (see Table 1). Employers from Poland actively looked east to fill gaps in the labour market. However, administrative obstacles for getting visas and related documents were difficult to overcome as shown by the discrepancy between the number of declarations of intent and actual number of work permits issued to Ukrainian citizens from 2013 to 2017.. Before 2017 Ukrainian citizens would have entered Poland on temporary visas for a few months at a time and then returned home. After the introduction of the visa-free regime 2 by the EU they did not need visas to enter Poland; however, permissions to work and residence permits ${ }^{3}$ were necessary if they intended to work for more than three months (see Table 1).

Many Ukrainians worked, studied and traveled not only in Poland, but to Czech Republic, Slovakia, Slovenia, Hungary, Russia and many other countries. However, the COVID-19 outbreak has ruined their everyday plans. European countries that were normally associated with freedom of movement had temporarily closed their internal (within the EU) and external borders in response to the pandemic. Border closures heavily affected the

\begin{tabular}{|c|c|c|}
\hline & $\begin{array}{c}\text { No. of Work Permits } \\
\text { issued to Ukrainian } \\
\text { citizens }\end{array}$ & $\begin{array}{c}\text { No. of Declarations } \\
\text { of Intent to Employ } \\
\text { Issued to Ukrainian } \\
\text { Citizens }\end{array}$ \\
\hline 2013 & 20,416 & 217,571 \\
\hline 2014 & 20,945 & 372,346 \\
\hline 2015 & 50,465 & 762,700 \\
\hline 2016 & 103,208 & $1,262,845$ \\
\hline 2017 & 192,547 & $1,714.891$ \\
\hline
\end{tabular}

Table 1. Number of Work Permits and Declarations of Intent Issued to Employ Ukrainian Citizens during 2013-2017. Data generated by Ministry of Family, Labour and Social Policy, Poland. Cited in Jaroszewicz (2018). whole European region, including its Eastern European neighbours. Ukraine aligned itself with the European and World Health Organisation (WHO/Europe) standards and locked external borders and all border crossings, declaring borders shut down both for foreigners from 16 March and for Ukrainian citizens by the end of the day of 27 March. Railway travel with Slovakia was stopped on 13 March and with Poland on 15 March (Ukrainian railway 2020). Ukrainian government cut all railway travel with other countries from 17 March and internal railway travel on 18 March until the end of quarantine period (initially it was set for 3 April, later prolonged to 22 May). Also, parliament announced that air travel was completely restricted from 17 March. Those decisions provoked some panic among thousands of Ukrainian citizens in Poland who rushed to return to their home country. Hundreds of people tried crossing the Polish-Ukrainian border on foot, risking their own health and health of others (see Figure 1).

According to the Public Health Center and Ministry of Healthcare report of 23 April, 93 percent of Ukrainians with confirmed cases of COVID-19 were infected abroad (Public Health Centre 2020). On 23 April, more than seven thousand Ukrainian citizens were infected with the novel coronavirus and a total of 187 died (Public Health Centre 2020). Ukrainian President Volodymyr Zelensky announced that all foreigners, apart from diplomats, without temporary or permanent residency status "will not be able to enter neither by plane, nor by car, nor by train" (UNIAN Information Agency 2020). Concerning Ukrainian citizens, tourists had been advised to return home prior to 17 March.

We asked 10 random Ukrainians who crossed borders by different means of transportation (by car, bus, on foot and by air) on their way to Ukraine from Poland, Czech Republic, Russia and Luhansk region what had changed on the border because of the COVID-19.4 Those were people who frequently crossed Ukrainian borders before the pandemic due to work and family reasons. That random questionnaire allowed us to

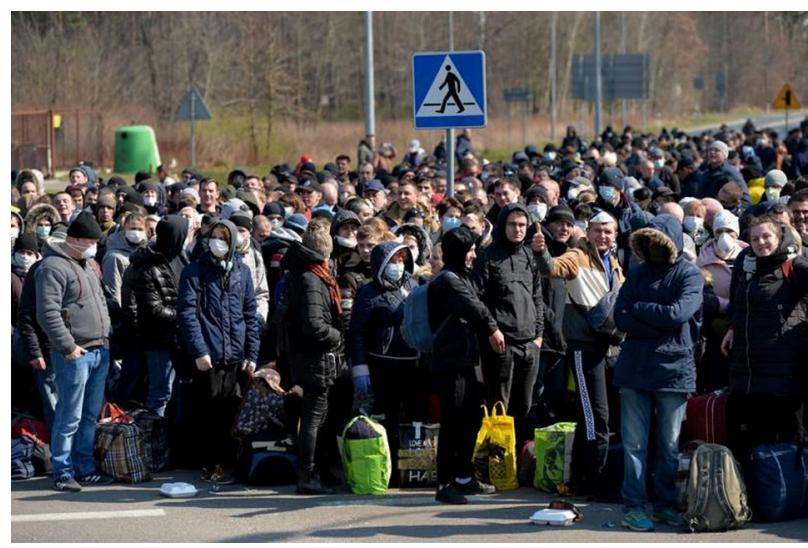

Figue 1. Ukrainian-Polish border. Ukrainians returning home after their government decision to close borders. Photo: European Pravda, https://www.eurointegration.com.ua/ 
better understand how Ukrainians felt themselves on the border right after the COVID-19 closures, whether they thought the border responses were adequate to the emergency and which early measures were taken to support their wellbeing. That information did not allow us to generalise or make solid conclusions. However, it let us select original impressions of how effective responses of the Ukrainian government to the emergency have been. This research is important given the government's ongoing efforts to build its social capital and trust among ordinary Ukrainians as well as its international reputation.

Ukrainians who crossed the Polish border on their return to Ukraine generally reported no changes or minor changes which took place on the Polish side. They reported that people and staff started wearing masks, gloves, and used sanitizers. However, Ukrainians felt safer on the Ukrainian side rather than on the Polish side of the border, mainly due to lack of safety measures (Figure 1). It was impossible to respect social distancing, for instance. On the Ukrainian side of the border, all people entering Ukraine underwent temperature screening and free express tests for COVID-19. All safety measures were voluntary apart from obligatory quarantine period of 14 days. People reported reduction in the number of vehicles on the border which together with restrictions concerning the use of public transport increased transportation costs through Ukraine drastically during those days. It became ten times more costly to get to any necessary destination point in Ukraine, according to an interview conducted over Skype.

Also, Ukrainians stated noticeable changes in staffing on the border: medical, social, and voluntary workers in addition to custom officers and police stayed on duty. Border-crossers were asked questions about their health and wellbeing which delayed significantly their return home. However, that delay was understood as justified by the majority of respondents and the process of border crossing since the beginning of pandemic had been perceived as mostly adequate. Respondents paid attention to a lack of some information on certain changes and new procedures during COVID-19. Most of their information came from friends and from Facebook; only limited information was obtained from official websites. One respondent who volunteered on the eastern border of Ukraine reported a serious decrease of number of people crossing the Luhansk/Ukraine (internal) border. The border crossing there slowed to 50 people instead of the usual 14,000 per day (Skype interview).

Apart from actions mentioned above, the Ukrainian government implemented other important measures on border management during the COVID-19 crisis. These included: 1) posting information about preventive measures adopted by the State Customs Service, including an interactive map detailing reduced crossing points, on the State Customs Service's website (State
Customs Service); 2) placing important information and updates for Ukrainian citizens travelling abroad on the Ministry of Foreign Affairs' (MFA) website (MFA of Ukraine, Updated 21 June 2020); and 3) developed a free and voluntary mobile application for smartphones called "Act at Home"5 for Ukrainians to stay connected with the latest government health information and track their social distancing and, when necessary, quarantines and isolation.

\section{Conclusion}

The closure of the borders led to a massive return of Ukrainian citizens working abroad, which progressively contributed to an increase in COVID-19 cases. Then, during April and May, the situation become steadier and under control. Further spread occurred due to internal movements of citizens around the country after the government relaxed quarantine measures. According to official government figures of October 2020, Ukraine had 250,538 laboratory-confirmed cases of COVID-19 in total, of which 4,779 people died (Ministry of Finance 2020). Moreover, due to a deteriorating healthcare system (OECD 2020), Ukraine's population became particularly vulnerable to the disease. According to the World Bank (2019), the country had a GDP per capita of just $\$ 3,659$, making it the poorest country in Europe.

The Ministry of Health of Ukraine developed criteria for "zoning" countries depending on the spread of COVID-19 per 100,000 people. It created a 'Red Zone' and a 'Green Zone' country lists. Citizens of countries on the 'Green Zone' list could come in with no quarantine period if they traveled directly from the country (see the government's website VisitUkraine.today). On 15 June, foreigners who were not citizens of countries with a significant prevalence of COVID-19 and had not been on the territory of such countries for the past 14 days were allowed to enter Ukraine" (Ministry of Internal Affairs 2020). Ukrainian checkpoints were "locked up" for three months since their initial closure. In June the country gradually emerged from strict quarantine measures. Ukraine officially reopened for tourism on 15 June, 2020, lifting the entry ban for foreigners and resuming maximum of commercial flights. As a result, the COVID-19 pandemic significantly influenced border traffic and changed border crossing dynamics in Ukraine. Demand for more stringent and technological management of border traffic regimes in areas of mobility, security, and public health has increased.

\section{Notes}

1 Regulation (EC) No 1931/2006 of the European Parliament and of the Council of 20 December 2006 laying down rules on local border traffic at the external land borders of the Member States and amending the provisions of the Schengen Convention. OJ L 405, 31.12.2006. 
2 As of 11 June 2017, the visa obligation for citizens of Ukraine who hold a biometric passport and want to travel to the Schengen zone for a short stay was abolished (Official Journal of the European Union 2017).

3 The main origin country of persons who received permits in Europe is Ukraine (500,000, 19 percent of all in Europe), 86 percent of them $(430,000)$ were issued in Poland. (Urząd do Spraw Cudzoziemców 2016).

4 We prepared a simple questionnaire in Ukrainian language about crossing the Ukrainian border since the beginning of COVID-19. Questionnaire contained information about personal safety, health measures, and other noticeable changes that border crossers encountered at their regular border crossing points after the virus outbreak. It was conducted in April and May 2020. Respondents answered questions by phone, skype, and email. With this paper we want to acknowledge the time and effort they spent. Therefore, special thanks go to Dmytro Rybalka, Pogorilyi Eduard, Morenets Elena, Rodionova Elena, Pronin Vitaliy, Luts Eduard, Zomareva Vlada and three other anonymous respondents from Ukraine.

5 The application is designed to maintain contact with the person and control the observance of obligatory selfisolation during the quarantine period. Its installation is voluntary. If a person chooses self-isolation with the Act at Home app, he or she must confirm this decision when passing the passport. Act at Home can only be installed by citizens with Ukrainian phone numbers $(+380)$.

\section{Works Cited}

Cabinet of Ministers of Ukraine. 2020. The Resolution of the Cabinet of Ministries of Ukraine from 11 March 2020 r. no. 211 "On the Expansion of the Coronavirus COVID-19 on the Territory of Ukraine due to the Coronavirus SARS CoV-2". Available: https://covid19.gov.ua/en

European Pravda. 2020. "На Польському Кордоні Утворилися Довжелезні Черги з Українців, Охочих Повернутись Додому ("Long Lines of Ukrainian People at the Polish Border Waiting to Return Home") (March 27). Available: https://www.eurointegration.com.ua/ news/2020/03/27/7108069/

Jaroszewicz, M. 2018. Migration from Ukraine to Poland: The Trend Stabilises. OSW (Ośrodek Studiów Wschodnich, Centre for Eastern Studies) Report.

Mingarelli, Hugues. 2017. Ukraine, EU to Be "in One Family Soon". UNIAN Info. Available: https://www.unian.info/ politics/1968744-ukraine-eu-to-be-in-one-family-soonmingarelli.html

Ministry of Digital Transformation of Ukraine. 2020. 'Act at Home' App is Launched to Counteract the Spread of COVID-19 in Ukraine. Available: https://www.kmu.gov.ua/ en/news/yak-pracyuye-zastosunok-dij-vdoma

Ministry of Internal Affairs. 2020. Ukraine. Available: https:// mvs.gov.ua/en/

Ministry of Finance. 2020. "Coronavirus in Ukraine". Available https://index.minfin.com.ua/reference/coronavirus/ ukraine/2020-03/
Ministry of Foreign Affairs of Ukraine. 2020. "Information for Ukrainian Citizens Travelling Abroad.” Available: https:// mfa.gov.ua/news/operativna-informaciya-shchodo-zahodiv-yaki-vzhivayutsya-inozemnimi-krayinami-z-protidiyi-rozpovsyudzhennyu-covid-19

OECD. 2020. The COVID-19 Crisis Response in Eastern Partnership Countries. Report.. Available: https://read. oecd-ilibrary.org/view/?ref=129_129637-ttbr2lwvsh\&title=COVID-19-Crisis-Response-in-EU-Eastern-PartnerCountries

Official Journal of the European Union. 2017. Regulation (EU) 2017/371 of the European Parliament and the Council of 1 March 2017 Amending Council Regulation (EC) No 539/2001 Listing the Third Countries Whose Nationals Must $\mathrm{Be}$ in Possession of Visas When Crossing the External Borders and Those Whose Nationals are Exempt from That Requirement (Ukraine). 19 April 2017. Brussels.

Public Health Centre of Ukraine. 2020. Update on the Spread of COVID-19 Coronavirus Infection. 29 July 2020. Available: https://www.kmu.gov.ua/en/news/operativna-informaciya-pro-poshirennya-koronavirusnoyi-infekciyi-2019-ncov-29-20

European Parliament. 2006. Regulation (EC) No 1931/2006 of the European Parliament and of the Council of 20 December 2006 Laying down Rules on Local Border Traffic at the External Land Borders of the Member States and Amending the Provisions of the Schengen Convention. OJ L 405, 31.12.2006.

International Organisation for Migration. 2016. "Migration as an enabler of development in Ukraine". A Study on the Nexus between Development and Migration-Related Financial Flows to Ukraine. Mission in Ukraine. Kyiv.

State Customs Service of Ukraine. 2020. "Обмеження під Час Карантину (Limitations During Quarantine)". Available: https://customs.gov.ua/en/ obmezhennia-pid-chas-karantinu\#scrollTop=0

UNIAN Information Agency. 2020. "Zelensky Addresses Ukrainians, Confirms Suspension of All Air Travel from March 17 (Video)". Available: https://www.unian.info/politics/10914764-zelensky-addresses-ukrainians-confirmssuspension-of-all-air-travel-from-march-17-video.html

Ukrainian Railway. 2020. International Passenger Railway Shuts from 17 March for the Duration of Quarantine. Press Centre. In Ukrainian. Available: https://www.uz.gov.ua/ press_center/up_to_date_topic/514363/

Urząd do Spraw Cudzoziemców. 2016. "Residence Permits For Foreigners in The EU" (November 8). Available: https://udsc. gov.pl/en/zezwolenia-pobytowe-dla-cudzoziemcow-w-ue/

Government Agency for Foreigners. 2016. "Residence Permits for Foreigners in the EU'. Warsaw. Available: ec.europa.eu/ eurostat/

Visit Ukraine Today. 2020. "Information and Rules for Staying in Ukraine". Available: https://visitukraine.today/

World Bank. 2019. "GDP per Capita. Ukraine". Available: https://data.worldbank.org/indicator/NY.GDP.PCAP. $\mathrm{CD}$ ?locations $=\mathrm{U}$

Yeliseyeu, A. 2014. "Keeping the Door Ajar: Local Border Traffic Regimes on the EU's Eastern Borders". FIIA report 41. 